\title{
Effect Of Rational Emotive Behavioral Therapy On Preventive Measures Of Transmission in The Family Of Pulmonary TB Patients
}

\author{
Nugrahaeni Firdausi, Pratiwi Yuliansari, Erwin Yektiningsih \\ ${ }^{I}$ Nursing Depertement, Akademi Keperawatan Pamenang \\ Corresponding author: nug f@yahoo.co.id
}

\begin{abstract}
Background: Pulmonary $\mathrm{TB}$ is an infectious disease caused by mycobacterium tuborkulosis and is contagious. The family of pulmonary TB patients plays a very important role in the transmission of pulmonary TB disease. Preliminary data collection shows that four out of five $(80 \%)$ families of pulmonary TB sufferers so far have gained knowledge about the transmission of pulmonary TB, but in their daily use personal protective equipment is rarely used. The family said they rarely wear masks because they feel fine without the masks, the family also feels wearing masks will hurt the feelings of people with pulmonary TB.

Purpose: This study aimed to determine the effect of Rational Emotive Behavior Therapy on preventive measures for transmission of patients with pulmonary TB.

Methods: This study used a quasy experiment research design with a non-randomized control group design pretest-posttest approach. The sample in this study was the family of pulmonary TB patients at UPTD Puskesmas Puhjarak Kediri who met the inclusion and exclusion criteria, with a sampling technique using purposive sampling. The independent variable of this study was Rational Emotive Behavioral Therapy and the dependent variable was family preventive measures. The instrument used to measure preventive measures for pulmonary TB transmission is a questionnaire which contains 12 questions, and for the independent variable of memory therapy is SAK research. The research data were processed using the Wilcoxon signed ranks test and Mann-Whitney. Alternative hypotheses are accepted if $\mathrm{p}<0.05$.

Results: The results showed that the Mann Whitney test results in the treatment and control groups at the time of the pretest showed a value of $p=0.690$ and at the posttest was $p=0.000$. Wilcoxon signed rank test results show in the treatment group after treatment $\mathrm{p}=0.005$, while in the control group when posttest was $\mathrm{p}=0.317$.

Conclusion: The results of the assessment of preventive measures for pulmonary TB transmission between the treatment group and the control group after the implementation of Rational Emotive Behavioral Therapy showed that there were differences in the value of preventive measures for pulmonary TB transmission between the treatment group and the control group after receiving Rational Emotive Behavioral Therapy.
\end{abstract}

Keywords: Family, Pulmonary TB, Preventive, Rational Emotive Behavioral Therapy 


\section{Journal Of Nursing Practice}

http://thejnp.org

ISSN: 2614-3488 (print); 2614-3496 (online)

Vol.3 No.2. April 2020. Page.193-203

\section{BACKGROUND}

Sustainable Development Goals (SDGs) is a world development agenda aimed at the welfare of humans and planet Earth. Sustainable Development Goals (SDGs) have 17 goals with 169 targets (WHO, 2016). One of the goals of the Sustainable Development Goals (SDGs) is to ensure a healthy life and to encourage welfare for all people at all ages (WHO, 2016). The Sustainable Development Goals (SDGs) launch the END-TB program and have 3 indicators of success, namely the reduction in the incidence of pulmonary TB in the world by $80 \%$ in 2030 compared to 2015 , the reduction in mortality by $90 \%$ in 2030 compared to 2015 , and 0 (zero) costs that need to be incurred by patients with pulmonary TB in the context of treating the disease (Christianto, 2019). Pulmonary TB is an infectious disease caused by mycobacterium tuborkulosis and is contagious (Wejse, 2009). Kemenkes RI (2015) mentions several factors causing pulmonary TB cases to continue to increase, including the low compliance with taking medication which is often caused by side effects of the drug. Research Hanif (2016) shows that family behavior that is lacking in preventive measures for pulmonary TB disease transmission is also a contributing factor to the increased incidence of pulmonary TB. Families of pulmonary TB sufferers have gained knowledge about pulmonary TB transmission, but in their daily use of personal protective equipment is rarely used, both by patients and their families. The family said they rarely wear masks because they feel fine without masks, wearing masks is also uncomfortable.

WHO states that $1 / 3$ of the world's population has been infected with tuberculosis. Every second one person is infected with tuberculosis. Pulmonary TB can strike from toddlers to old age. There are 9.6 million cases of pulmonary TB in the world and $58 \%$ of cases occur in Southeast Asia and Africa. Indonesia (10\%), and China (10\%). Indonesia is now ranked second with the highest TB burden in the world (WHO, 2016). Based on the survey results, the prevalence of pulmonary TB in 2013, the prevalence of positive smear pulmonary TB per 100 thousand population aged 15 years and over by 257. East Java Province is one of the contributors to the second highest number of pulmonary tuberculosis findings under West Java Province (WHO, 2016). In 2012, the number of positive smear (case detection rate) was $63.03 \%$ with the number of new cases (positive and negative) as many as 41, 472 patients and new positive smear as much as 25, 618 cases. Data from the city of Kediri in 2015 showed that there were 167 pulmonary TB sufferers. The total number of pulmonary TB cases was 273 cases, positive smear treated by 140 people $(83.83 \%)$, while the cure rate for smear TB cases + was 109 people $(77.86 \%)$ (Kediri District Health Profile 2015). In 2016 the estimated TB sufferers in Kediri District reached 1,656 people (Kemkes, 2016).

Pulmonary TB disease is caused by mycobacterium tuberculosis which spreads through the lymphatic channels to the regional lymph glands. This spread causes inflammation in the channel of lymph (lymphangitis) and in the affected lymph nodes (lymphadenitis) (Price \& Wilson, 2005). Symptoms of pulmonary TB can cause fever, anorexia malaise, nausea, vomiting, fatigue so that the impact can be an increase in body temperature, changes in nutrition less than needs and intolerance of activity (Price \& 


\section{Journal Of Nursing Practice}

http://thejnp.org

ISSN: 2614-3488 (print); 2614-3496 (online)

Vol.3 No.2. April 2020. Page.193-203

Wilson, 2005). The source of transmission of pulmonary TB is positive smear TB patients who can easily transmit it to others (Safithri, 2017). Transmission occurs when coughing or sneezing, the patient spreads germs into the air in the form of sputum droplets (droplet nuclei). Transmission occurs in a room where sputum sparks are in a long time (Safithri, 2017). The family is a person who is at risk of pulmonary TB transmission (Jaji, 2010). The less optimal role of the family in providing care and prevention of TB transmission often impacts other family members. TB patients can transmit the disease to family members and those around them, as a result the number of pulmonary TB sufferers tends to increase (Marwansyah \& Sholikhah, 2015).

The management of pulmonary TB has so far been using the DOTS strategy and one of the components is OAT which must be carried out routinely for 6 months and should not be broken up with direct supervision by the Drugs Supervisor (PMO) (Susiyanti, 2019). Management of patients and families of pulmonary TB has been focused on the physical, even though the number of morbidity in pulmonary TB patients can also affect the psychological. Rational Emotive Behavioral Therapy was chosen by researchers to improve family preventive measures against pulmonary TB transmission. Safa's research (2019) on the Effectiveness of Rational Emotive Behavior Therapy shows that 90\% can reduce symptoms of psychological disorders (cognitive, affective, and somaticbehavioral). Rational Emotive Behavior Therapy uses a counseling approach that emphasizes the togetherness and interaction between thinking with common sense, feelings and behavior, and emphasizes deep changes in ways of thinking and feeling that result in changes in feelings and behavior (Winkel, 2005). Rational Emotive Behavior Therapy is expected to increase the prevention of transmission to families with pulmonary TB.

\section{OBJECTIVE}

This study aimed to determine the effect of Rational Emotive Behavior Therapy on preventive measures for transmission of patients with pulmonary TB.

\section{METHODS}

This study used a quasy experiment research design with a non-randomized control group design pretest-posttest approach. The sample in this study was the family of pulmonary TB patients at UPTD Puskesmas Puhjarak Kediri who met the inclusion and exclusion criteria, with a sampling technique using purposive sampling. The independent variable of this study was Rational Emotive Behavioral Therapy and the dependent variable was family preventive measures. The research process was conducted in MayJune 2019, starting after obtaining permission from the Kediri District Health Office which oversees the UPTD Puskesmas Puhjarak Kediri as a research site.

The sample in this study was the families of pulmonary TB patients in the working area of the UPTD Puskesmas Puhjarak Kediri who met the sample criteria, so that a total of 20 respondents were obtained. Respondents were then divided into treatment and control groups, each group of 20 respondents. Before being given a Rational Emotive 


\section{Journal Of Nursing Practice}

http://thejnp.org

ISSN: 2614-3488 (print); 2614-3496 (online)

Vol.3 No.2. April 2020. Page.193-203

Behavior Therapy the data was taken by taking the client's preventive actions using an instrument used to measure preventive measures which contain 12 questions. The instrument used to measure preventive measures for pulmonary TB transmission is an instrument made by researchers themselves which contains 12 questions in the good category 29-36, sufficient 21-28, and less 12-20. This measuring instrument has 12 statements, with some favorite items (items number 1, 2, 7, 8, 9, 10, 11, and 12) and unfavorable items (items number 3, 4, 5, and 6). Score 3 for Always, 2 for Sometimes, and 1 for Never, while for unfavorable items the score is the opposite. The instrument for the independent variable of memory therapy is SAK research.

Rational Emotive Behavior Therapy was carried out four sessions in eight meetings with the treatment group respondents, while the control group respondents only carried out daily activities. At the end of the meeting a retrieval of preventive measures was taken. The research data were processed using the Wilcoxon signed ranks test to determine differences before and after the implementation of an intervention in a sample, and the Mann-Whitney test was performed to determine the comparison between groups that were treated and not treated. Alternative hypotheses are accepted if $p<0.05$. The results of the study are expected to be one way to reduce the incidence of pulmonary TB in Indonesia.

\section{RESULTS}

The results of observations about the characteristics of the study respondents which included age, sex, education, occupation, marital status, and duration of illness of respondents with pulmonary TB at the UPTD Puskesmas Puhjarak Kediri will be described below:

Table 1. Results of observations of the characteristics of respondents of pulmonary TB patients in the UPTD Puskesmas Puhjarak in May - June 2019

\begin{tabular}{|c|c|c|c|c|c|}
\hline \multirow{3}{*}{ No } & \multirow{3}{*}{$\begin{array}{l}\text { Characteristics } \\
\text { Sex }\end{array}$} & \multicolumn{4}{|c|}{ Pulmonary TB Patients } \\
\hline & & \multicolumn{2}{|c|}{ Control Group } & \multicolumn{2}{|c|}{$\begin{array}{c}\text { Treatment } \\
\text { Group }\end{array}$} \\
\hline & & $\mathrm{f}$ & $\%$ & $\mathrm{f}$ & $\%$ \\
\hline 1. & Male & 6 & 60 & 5 & 50 \\
\hline \multirow[t]{3}{*}{2.} & Female & 4 & 40 & 5 & 50 \\
\hline & $\sum$ & 10 & 100 & 10 & 100 \\
\hline & Age & $\mathrm{f}$ & $\%$ & $\mathrm{f}$ & $\%$ \\
\hline 1. & $<25$ & 0 & 0 & 1 & 10 \\
\hline 2. & $25-35$ & 3 & 30 & 3 & 30 \\
\hline 3. & $36-45$ & 0 & 0 & 1 & 10 \\
\hline 4. & $46-55$ & 3 & 30 & 2 & 20 \\
\hline \multirow[t]{3}{*}{5.} & $>55$ & 4 & 40 & 3 & 30 \\
\hline & $\sum$ & 10 & 100 & 10 & 100 \\
\hline & Education & $\mathrm{f}$ & $\%$ & $\mathrm{f}$ & $\%$ \\
\hline 1. & SD & 6 & 60 & 3 & 30 \\
\hline 2. & SMP & 2 & 20 & 4 & 40 \\
\hline \multirow[t]{3}{*}{3.} & SMA & 2 & 20 & 3 & 30 \\
\hline & $\sum$ & 10 & 100 & 10 & 100 \\
\hline & Occupation & $\mathrm{f}$ & $\%$ & $\mathrm{f}$ & $\%$ \\
\hline
\end{tabular}


Journal Of Nursing Practice

http://thejnp.org

ISSN: 2614-3488 (print); 2614-3496 (online)

Vol.3 No.2. April 2020. Page.193-203

\begin{tabular}{llrrrl}
\hline & & & & & \\
1. & Work & 9 & 90 & 5 & 50 \\
\hline 2. & Did not work & 1 & 10 & 5 & 50 \\
\hline & $\sum$ & 10 & 100 & 10 & 100 \\
\hline & Marital Satus & $\mathrm{f}$ & $\%$ & $\mathrm{f}$ & $\%$ \\
\hline 1. & Marriage & 10 & 100 & 7 & 70 \\
\hline 2. & Single & 0 & 0 & 3 & 30 \\
3. & Widow & 0 & 0 & 0 & 0 \\
4. & Widower & 0 & 0 & 0 & 0 \\
\hline & $\sum$ & 10 & 100 & 10 & 100 \\
\hline & Durration of Illness & $\mathrm{f}$ & $\%$ & $\mathrm{f}$ & $\%$ \\
\hline 1. & $<3$ month & 4 & 40 & 2 & 20 \\
2. & 3 Month 1 year & 5 & 50 & 6 & 60 \\
3. & $1-2$ years & 1 & 10 & 2 & 20 \\
4. & $>$ years & 0 & 0 & 0 & 0 \\
\hline & $\sum$ & 10 & 100 & 10 & 100 \\
\hline
\end{tabular}

The results of observations on the family demographic data of pulmonary TB patients showed that the gender of the family of pulmonary TB patients in the control group were six men and four women, while in the treatment group there were 5 male respondents and

five

women

The results of observations of the age range of respondents in the family respondents of pulmonary TB patients in the control group in the age range 25-35 were three respondents, aged 46-55 years as many as three respondents, and as many as four respondents were aged $>55$ years, while in the treatment group as many as one respondent in the age range $<25$ years, three respondents in the age range 25-35 years, one respondent in the age range 36-45 years, two respondents in the age range 46-55 years, and three respondents aged > 55 years

old.

The results of observations of the education of family respondents of pulmonary TB patients in the control group were six respondents with primary education, two respondents with secondary education, and two respondents with high education, while in the treatment group were three respondents with primary education, four respondents with secondary education, and three respondents have a high school education.

The results of observations of the occupational status of family respondents of pulmonary TB patients in the control group showed that as many as nine respondents worked, and one respondent did not work, while in the treatment group as many as five respondents worked, and five respondents did not work.

The results of observations of the marital status of respondents of pulmonary TB patients in the control group showed that ten respondents were married, while in the treatment group, as many as seven respondents were married, and three respondents were single.

The results of observations of long time caring for patients with pulmonary TB showed data in the control group were as many as four respondents taking care within a period of $<3$ months, five respondents caring for a period of 3 months- 1 year, and as many as one resonden caring for a period of 1- 2 years, whereas in the treatment group as many as two 


\section{Journal Of Nursing Practice}

http://thejnp.org

ISSN: 2614-3488 (print); 2614-3496 (online)

Vol.3 No.2. April 2020. Page.193-203

respondents treated within a period of $<3$ months, six respondents treated within a period of 3 months- 1 year, and as many as two respondents treated within a period of 1-2 years.

The results of the assessment of preventive measures of transmission between the treatment group and the control group before the implementation of Rational Emotive Behavioral Therapy can be seen in the following table:

Table 2. Results of assessment of preventive measures of transmission between the treatment group and the control group before the implementation of Rational Emotive Behavioral Therapy

\begin{tabular}{ccc}
\hline $\begin{array}{c}\text { Preventive measures of } \\
\text { transmission }\end{array}$ & Treatment Group & Pretest \\
\cline { 2 - 3 } & & Control Group \\
\hline Mann Whitney & $\mathrm{p}=0,690$ \\
\hline
\end{tabular}

Mann Whitney test results in the treatment group and the control group at the time of the pretest showed a value of $p=0.690$ with $\alpha<0.05$ which means there is no difference in the value of preventive action between the treatment group and the control group before getting Rational Emotive Behavioral Therapy.

The results of evaluating preventive measures in the treatment group and the control group before and after the implementation of Rational Emotive Behavioral Therapy can be seen in the following table:

Table 3.The results of the assessment of preventive measures of transmission in the treatment group and the control group before and after the implementation of Rational Emotive Behavioral Therapy

\begin{tabular}{|c|c|c|c|c|c|c|c|c|}
\hline \multirow{3}{*}{$\begin{array}{c}\text { Preventive measures of } \\
\text { transmission }\end{array}$} & \multicolumn{5}{|c|}{ Treatment Group } & \multicolumn{3}{|c|}{ Control Group } \\
\hline & \multicolumn{2}{|c|}{ Pretest } & \multicolumn{3}{|c|}{ Posttest } & \multirow{2}{*}{$\frac{\text { Pretest }}{\%}$} & \multicolumn{2}{|c|}{ Posttest } \\
\hline & $\mathrm{f}$ & $\%$ & $\mathrm{~F}$ & $\%$ & $\mathrm{f}$ & & $\mathrm{f}$ & $\%$ \\
\hline Good & 0 & 0 & 9 & 90 & 0 & 0 & 0 & 0 \\
\hline Enough & 10 & 100 & 1 & 10 & 10 & 100 & 10 & 100 \\
\hline Less & 0 & 0 & 0 & 0 & 0 & 0 & 0 & 0 \\
\hline$\sum$ & 10 & 100 & 10 & 100 & 100 & 100 & 10 & 100 \\
\hline Wilcoxon signed rank test & & & & & & & 0,3 & \\
\hline
\end{tabular}

The results of the evaluation of preventive measures for pulmonary TB transmission in the treatment group showed that 10 respondents had adequate precautions at the time of the pretest, while in the posttest as many as nine respondents had good preventive measures for pulmonary TB transmission, and one respondent had sufficient pulmonary TB transmission preventive measures. In the control group showed the value of preventive measures for pulmonary TB transmission when the pretest of ten respondents had sufficient pretest value, and when the posttest of the preventive action for pulmonary TB transmission was quite as many as ten respondents. The results of data analysis of preventive measures in the treatment group after receiving therapy there was a significant difference after being given therapy, with $p=0.005$, whereas in the control group who 
were not given therapy, no significant difference was seen in the posttest value with $\mathrm{p}=$ 0.317 .

The results of the assessment of preventive measures of transmission between the treatment group and the control group after the implementation of Rational Emotive Behavioral Therapy can be seen in the following table:

Table 4. Results of assessment of preventive measures of transmission between the treatment group and the control group before the implementation of Rational Emotive Behavioral Therapy

\begin{tabular}{ccc}
\hline $\begin{array}{c}\text { Preventive measures of } \\
\text { transmission }\end{array}$ & Treatment Group & Posttest \\
\cline { 2 - 3 } & & $\mathrm{p}=0,000$ \\
\hline Mann Whitney & & Control Group \\
\hline
\end{tabular}

Mann Whitney test results in the treatment group and the control group at the time of the posttest showed data $p=0,000$ with $\alpha<0.05$, which means there are differences in the value of preventive measures between the treatment group that received Rational Emotive Behavioral Therapy and the control group who did not get Rational Emotive Behavioral Therapy.

\section{DISCUSSION}

The results of the assessment of preventive measures for pulmonary TB transmission between the treatment group and the control group prior to the implementation of Rational Emotive Behavioral Therapy are that there is no difference in the value of preventive measures for pulmonary TB transmission between the treatment group and the control group before getting Rational Emotive Behavioral Therapy. The results of the assessment of preventive measures for pulmonary TB transmission show that the data on preventive measures for pulmonary TB transmission obtained from respondents were homogeneous, and that between the treatment and control groups there was no background difference between the two before the implementation of Rational Emotive Behavioral Therapy. Strict control is needed in research, because the behavior of a person's preventive pulmonary TB transmission can be influenced by external stimuli or stimuli (Skinner, 2016). Based on the results of the evaluation of preventive measures for pulmonary TB transmission between respondents in the control group and the treatment group shows that without the implementation of Rational Emotive Behavioral Therapy, respondents have the same assessment of pulmonary TB preventive measures.

The results of the assessment of preventive measures for pulmonary TB transmission in the treatment group after receiving therapy there were significant differences after the implementation of Rational Emotive Behavioral Therapy. Respondents after Rational Emotive Behavior Therapy have experienced an increase in the prevention of pulmonary TB transmission. One of the goals of the implementation of Rational Emotive Behavior Therapy according to Thahir (2016) is to improve and change 


\section{Journal Of Nursing Practice}

http://thejnp.org

ISSN: 2614-3488 (print); 2614-3496 (online)

Vol.3 No.2. April 2020. Page.193-203

all irrational and illogical behavior and thought patterns to be rational and more logical so that clients can develop themselves. Respondents who have an irrational belief in the prevention of pulmonary TB transmission, which is feeling uncomfortable when wearing a mask and feel fine without a mask. Respondents also felt that the use of personal protective equipment would hurt the feelings of people with pulmonary TB who lived together in one house. After the Rational Emotive Behavior Therapy was carried out, respondents began to understand the importance of pulmonary $\mathrm{TB}$ transmission to the health, personal safety of the respondents themselves and also patients with pulmonary TB. The results of the evaluation of preventive measures for pulmonary TB transmission in the treatment group showed that 10 respondents had adequate precautions at the time of the pretest, while in the posttest as many as nine respondents had good preventive measures for pulmonary TB transmission, and one respondent had sufficient pulmonary TB transmission preventive measures. Based on research by Palmer \& Gyllensten (2008) Rational Emotive Behavior Therapy can be used to prevent psychological problems in respondents, so they can change behavior for the better. Changes in a person's behavior will be able to improve the health of the individual. The results of the posttest preventive measures for pulmonary TB transmission in the control group that were not implemented by the Rational Emotive Behavior Therapy showed no significant difference. Respondents in daily life do not show changes in the behavior of preventive measures for pulmonary TB transmission. The results of evaluation of preventive measures for pulmonary TB transmission in the control group showed the value of preventive measures for pulmonary TB transmission when the pretest of ten respondents had a sufficient pretest value, and when the posttest for the prevention of pulmonary TB transmission was quite as many as ten respondents. Changes in the value of posttest preventive measures for pulmonary TB transmission can be influenced by external stimuli or stimuli (Skinner, 2016).

The results of the assessment of preventive measures for pulmonary TB transmission between the treatment group and the control group after the implementation of Rational Emotive Behavioral Therapy showed that there were differences in the value of preventive measures for pulmonary TB transmission between the treatment group and the control group after receiving Rational Emotive Behavioral Therapy. Rational Emotive Behavioral Therapy is used to identify dysfunctional emotions and behaviors that hinder more effective conditions; linking dysfunction with irrational trust; encouraging clients to reduce control by irrational beliefs in their lives and adopting more self-confidence and practices related to their goals so as to reduce bad emotions and behavior and improve their pleasant lives. (Betts, 2002). The increase in the value of preventive measures for pulmonary TB transmission that occurs in respondents with pulmonary TB due to the implementation of Rational Emotive Behavioral Therapy, while the results of preventive measures for pulmonary TB transmission in the control group due to not getting Rational Emotive Behavioral Therapy. 


\section{STUDY LIMITATIONS}

Research on the effect of Rational Emotive Behavior Therapy on the prevention of transmission of pulmonary TB patients has limitations, namely: Strict control over the placement of samples based on demographics evenly in each group can not be fully implemented, Control in minimizing interactions between respondents and the surrounding environment, in this case family and neighbors, cannot be done optimally, Control in observing research respondents in full on a daily basis cannot yet be carried out.

\section{CONCLUSIONS}

The results of the assessment of preventive measures for pulmonary TB transmission between the treatment group and the control group prior to the implementation of Rational Emotive Behavioral Therapy are that there is no difference in the value of preventive measures for pulmonary TB transmission between the treatment group and the control group before getting Rational Emotive Behavioral Therapy. The results of the assessment of preventive measures for pulmonary TB transmission in the treatment group after receiving therapy there were significant differences after the implementation of Rational Emotive Behavioral Therapy. The results of the assessment of preventive measures for pulmonary TB transmission between the treatment group and the control group after the implementation of Rational Emotive Behavioral Therapy showed that there were differences in the value of preventive measures for pulmonary TB transmission between the treatment group and the control group after receiving Rational Emotive Behavioral Therapy. Tight control of sample placement based on demographics evenly in each group and the role of the environment as an external stimulus must be controlled.

\section{ACKNOWLEDGMENT}

All research funding came from Kemenristek DIKTI grant, and I am express my gratitude to the Kemenristek Dikti for providing the opportunity to participate in this research. This research has received approval from respondents, and the publication of articles with the principle of confidentiality of respondents. 


\section{Journal Of Nursing Practice}

http://thejnp.org

ISSN: 2614-3488 (print); 2614-3496 (online)

Vol.3 No.2. April 2020. Page.193-203

\section{REFERENCES}

Betts, J. C., Lukey, P. T., Robb, L. C., McAdam, R. A., \& Duncan, K. (2002). Evaluation of a nutrient starvation model of Mycobacterium tuberculosis persistence by gene and protein expression profiling. Molecular microbiology, 43(3), 717-731. https://doi.org/10.1046/j.1365-2958.2002.02779.x

Christianto, D., Raras, T. Y. M., Sumarno, S., Arthamin, M. Z., Astuti, T., Sardjono, T. W., \& Noorhamdani, A. S. (2019). Efek Pemberian Protein Rekombinan Fusi ESAT6-CFP10 Mycobacterium tuberculosis terhadap Persentase IL2 dan IL10 yang Dipresentasikan Sel T CD8 pada Kultur PBMC. Jurnal Kedokteran Brawijaya, 30(3), 202-208. http://dx.doi.org/10.21776/ub.jkb.2019.030.03.7

HANIF, D. Z. (2016). Hubungan Tingkat Pengetahuan Keluarga Tentang Tb Paru Dengan Upaya Keluarga Dalam Pencegahan Penularan Infeksi Tb Paru Di Wilayah Kerja Puskesmas Karang Taliwang Kota Mataram Ntb Penelitian Korelasional. (Doctoral dissertation, Universitas Airlangga).

Jaji. (2010). Upaya Keluarga dalam Pencegahan Penularan Tuberkulosis (Tb) Paru ke Anggota Keluarga Lainnya di Wilayah Kerja Puskesmas Sidorejo Pagaralam Tahun 2010. Jurnal Ilmu Kesehatan Masyarakat, 1 (3). 177-187.

Kemenkes, R. I. (2015). Profil Kesehatan Indonesia 2015. Jakarta: Kementerian Kesehatan Republik Indonesia.

Kemkes. (2016). Profil Kesehatan Kota Kediri Tahun 2015. Dinas Kesehatan Kota Kediri.

Marwansyah, M., \& Sholikhah, H. H. (2015). The Infl uence of Empowering TB (Tuberculosis) Patients' Family on Capability of Implementing The Family Health Task in Martapura and Astambul Public Health Center Areas in Banjar District. Buletin Penelitian Sistem Kesehatan, 18(4), 407-419.

Palmer, S., \& Gyllensten, K. (2008). How cognitive behavioural, rational emotive behavioural or multimodal coaching could prevent mental health problems, enhance performance and reduce work related stress. Journal of Rational-Emotive \& Cognitive-Behavior Therapy, 26(1), 38-52. https://doi.org/10.1007/s10942-007$\underline{0069-y}$

Price, S. A., \& Wilson, L. M. C. (2005). Patofisiologi Konsep Klinik Proses-Proses Penyakit. Buku 2 Edisi 4. Jakarta: EGC.

Safa, M., Mirab Zadeh Ardekani, K., Tabarsi, P., Ghassem Boroujerdi, F., \& Hajizadeh, F. (2019). The Effectiveness of REBT Psychotherapy Approach on Reducing Cognitive Distortions in Hospitalized Tuberculosis Patients. Journal of Medical Council of Iran, 36(1), 34-40.

Safithri, F. (2017). Diagnosis TB Dewasa dan Anak Berdasarkan ISTC (International Srandard for TB Care). Saintika Medika: Jurnal Ilmu Kesehatan dan Kedokteran Keluarga, 7(2). 57-67. https://doi.org/10.22219/sm.v7i2.4078

Skinner, D., \& Claassens, M. (2016). It's complicated: why do tuberculosis patients not initiate or stay adherent to treatment? A qualitative study from South Africa. BMC infectious diseases, 16(1), 712. https://doi.org/10.1186/s12879-016-2054-5

Susiyanti, E. (2019). Hubungan Antara Karakteristik Pengawas Minum Obat (PMO) Dengan Konversi Tb Paru Kasus Baru Di Puskesmas Panjang Bandar Lampung Tahun 2017. Skripsi. Universitas Lampung.

Thahir, A., \& Rizkiyani, D. (2016). Pengaruh Konseling Rational Emotif Behavioral Therapy (REBT) dalam Mengurangi Kecemasan Peserta Didik Kelas VIII SMP Gajah Mada Bandar Lampung. KONSELI: Jurnal Bimbingan dan Konseling (EJournal), 3(2), 191-205. 
Wejse, C., Gomes, V. F., Rabna, P., Gustafson, P., Aaby, P., Lisse, I. M., ... \& Sodemann, M. (2009). Vitamin D as supplementary treatment for tuberculosis: a double-blind, randomized, placebo-controlled trial. American journal of respiratory and critical care medicine, 179(9), 843-850. https://doi.org/10.1164/rccm.200804-5670C

Winkel, W. S., \& Hastuti, M. S. (2005). Bimbingan dan konseling di institusi pendidikan. Media Abadi.

World Health Organization. (2016). World health statistics 2016: monitoring health for the SDGs sustainable development goals. World Health Organization. 